Политика и общество $2(98) \cdot 2013$

Н.В. Филина

\title{
ФАКТОРЫ СОЦИАЛЬНО-ПОЛИТИЧЕСКОЙ ПРИВЛЕКАТЕЛЬНОСТИ РЕЛИГИОЗНЫХ ОРГАНИЗАЦИЙ
}

\begin{abstract}
Аннотация: Автором исследуются различные аспекты социально-политической привлекательности религиозных организаций в современной России, а также выделяются критерии социально-политической привлекательности. Анализируются модели и формьл взаимодействия органов государственной власти с религиозньми организациями. При рассмотрении с практической точки зрения взаимодействия органов государственной власти и религиозных организаџий автором выделяются приоритетные направления социильно-политической деятельности религиозных организаций.
\end{abstract}

Ключевые слова: Политология, соччиально-политическая привлекательность, религиознье организации, нетрадиционные религиозные организации, традиционные религиозные организации, факторы привлекательности, модели взаимодействия, формы взаимодействия, направления сочиально-политической деятельности, сочиильно-политические прочессы

$\Gamma$ حлобальные изменения в социально-политических процессах, происходящих в современном мире, обострили противоречия в обществе. Изменились ценностные ориентиры, мировоззрение, мироощущение. Всё это привело к всестороннему политико-социальному изменению в общественной жизни. Возникает необходимость при изучении социальнополитических факторов учитывать религиозные, этнические, культурные, социальные, антропологические характеристики общества.

Вторая половина $\mathrm{XX}$ века существенным образом изменила роль религиозных организаций в социальнополитическом процессе. На смену рухнувшей модели советского взаимодействия государства и религиозных организаций возникла необходимость создать новую модель этих взаимоотношений, которая должна отвечать всем социально-политическим и правовым требованиям современной России. В многоконфессиональном государстве всегда будет противостояние между традиционными и нетрадиционными религиозными организациями.

Таким образом, вопрос о социально-политической привлекательности религиозных организаций в современной России становиться актуальным.

Природа этого вопроса носит политический характер. В связи с этим возникает ряд вопросов. Имеет ли право религиозная организация быть субъектом в социально-политическом процессе? Какие критерии оказывают воздействие на социально-политическую привлекательность религиозных организаций? Ответ на эти вопросы во многом зависит от того, что в данном случае понимается под политикой, социально-политическим процессом, а также под социально-политической привлекательностью религиозных организаций, какие смыслы и ограничения подразумеваются при оперировании этими политологическими категориями.

В толковом словаре русского языка С.И. Ожегова, можно найти необходимые категории. Так социальный - общественный, относящийся к жизни людей и их отношениям в обществе. ${ }^{1}$

Процесс - ход, развитие какого-нибудь явления, последовательная смена состояний в развитии чего-нибудь. ${ }^{2}$

Политика - деятельность органов государственной власти и государственного управления, отражающая общественный строй и экономическую структуры страны, а также деятельность общественных классов, партий и других классовых организаций, общественных группировок, определяемая их интересами и целями. ${ }^{3}$

\footnotetext{
${ }^{1}$ Толковый словарь С.И. Ожегова, Н.Ю. Шведовой [Электронный ресурc]. - URL: http://www.jobtoday.com.ua/slovar/ slovo_search.php (дата обращения 20.01.2013).

2 Толковый словарь С.И.Ожегова, Н.Ю. Шведовой [Электронный ресурc]. - URL: http://www.jobtoday.com.ua/slovar/ slovo_search.php?pg=11\&cb=2\&keyw=процесc $\&$ jcode $=$ (дата обращения 20.01.2013).

3 Толковый словарь С.И.Ожегова, Н.Ю. Шведовой [Электронный ресурc]. - URL: http://www.jobtoday.com.ua/slovar/ slovo_search.php?pg=4\&cb=1\&keyw=политика\&jcode $=$ (дата обращения 20.01.2013).
} 
Государство и гражданское общество

Политический процесс можно определить как упорядоченную последовательность единичных действий и взаимодействий политических акторов, как правило, создающих и воссоздающих политические институты.

Социальный процесс - серия явлений или взаимодействий, происходящих в организации, структуре групп меняющих отношения между людьми или между составными элементами сообщества.

Таким образом, под социально-политическим процессом стоит понимать серию явлений или взаимодействий происходящих в отношениях между людьми (сообществом) и политическими субъектами.

Социально-политическая привлекательность религиозных организаций - это естественное качество или состояние религиозной организации, не вызывающее раздражение, а наоборот, манящее, порождающее некое притяжение, симпатию со стороны социально-политических субъектов.

Если мы принимаем мнение о том, что религиозные институты как теоретически, так и практически могут участвовать в социально-политических процессах, то необходимо обозначить круг взаимодействий, привлекательных форм работы с социально-политическими субъектами применительно к современной России. Очевидно, что для нашей страны из всех религиозных объединений особый интерес будут представлять те религиозные организации, которые обладают особым статусом. Именно они могут транслировать ценности в масштабе всей социально-политической системы и таким образом становиться значимыми акторами в процессе построения новой, социально-политической реальности.
Опыт взаимодействия религиозных организаций с государственными органами власти показывает, что значимые позиции отданы Русской православной церкви. В мире сконцентрирован опыт нормативных регуляций сотрудничества религиозных организаций и государства. Практика сотрудничества религиозных организаций с государственными органами власти позволяет выделить следующие статусы: статус государственной (официальной) религии; статус традиционной религии; статус нетрадиционной религии.

В мировом сообществе, накоплен опыт взаимодействия государственных институтов власти с религиозными организациями который выражается в договорных отношениях, в международной деятельности, в регулярных субсидиях, в налогообложении, в специальных видах налогов в пользу религиозных организаций, в использовании и содержании имущества, в совместных акциях, в неформальном сотрудничестве.

В современной России предпочтительны следующие виды сотрудничества: договор (соглашение), регулярные субсидии, разовые субсидии, разовые совместные акции и неформальное сотрудничество, специальный режим налогообложения; специальные виды налогов в пользу религиозной организации; возвращение имущества принадлежащего религиозным организациям до 1917 года; внедрение религии в образовательный процесс.

Опыт взаимодействия органов государственной власти и местного самоуправления с религиозными организациями в современной России можно представить в виде таблицы сделанной по материалам интернет отчётов, докладов, органов государственной власти, официальных сайтов религиозных организаций.

Модели и формы взаимодействия органов государственной власти и местного самоуправления с религиозными организациями в современной России

\begin{tabular}{|c|c|c|c|c|c|c|}
\hline \multirow[t]{2}{*}{$\begin{array}{c}\text { Название религиоз- } \\
\text { ной организации }\end{array}$} & \multirow{2}{*}{$\begin{array}{c}\text { Статус } \\
\text { традицион- } \\
\text { ной религии } \\
\text { (количество } \\
\text { субъектов) }\end{array}$} & \multicolumn{2}{|c|}{$\begin{array}{c}\text { Договорные отношения } \\
\text { о сотрудничестве } \\
\text { (количество) }\end{array}$} & \multirow[t]{2}{*}{$\begin{array}{c}\text { Получение } \\
\text { разовых } \\
\text { субсидий }\end{array}$} & \multicolumn{2}{|c|}{$\begin{array}{c}\text { Неформальное сотрудни- } \\
\text { чество (количество дого- } \\
\text { воренностей) }\end{array}$} \\
\hline & & $\begin{array}{l}\text { На феде- } \\
\text { ральном } \\
\text { уровне }\end{array}$ & $\begin{array}{c}\text { На уровне } \\
\text { субъекта } \\
\text { федерации }\end{array}$ & & $\begin{array}{l}\text { На феде- } \\
\text { ральном } \\
\text { уровне }\end{array}$ & $\begin{array}{c}\text { На уровне } \\
\text { субъекта } \\
\text { федерации }\end{array}$ \\
\hline $\begin{array}{l}\text { Русская православная } \\
\text { церковь }{ }^{4}\end{array}$ & 2 & 25 & 188 & $\begin{array}{l}\text { регулярно } \\
\text { получают }\end{array}$ & не выявлено & 35 \\
\hline $\begin{array}{l}\text { Русская Православная } \\
\text { старообрядческая } \\
\text { церковь }^{5}\end{array}$ & 1 & не выявлено & не выявлено & получают & не выявлено & не выявлено \\
\hline
\end{tabular}

${ }^{4}$ Официальный сайт Русской Православной Церкви [Электронный ресурс]. - URL: http://www.patriarchia.ru/ дата (обращения 20.01.2013)
${ }^{5}$ Официальный сайт Русской Православной старообрядческой Церкви [Электронный ресурc]. - URL: http://rpsc.ru/ (дата обращения 20.01.2013) 


\section{Политика и общество 2 (98) • 2013}

\begin{tabular}{|c|c|c|c|c|c|c|}
\hline $\begin{array}{l}\text { Древлеправославная } \\
\text { церковь }{ }^{6}\end{array}$ & 1 & не выявлено & не выявлено & получают & не выявлено & не выявлено \\
\hline $\begin{array}{l}\text { Центральное духовное } \\
\text { управление мусульман } \\
\text { России }\end{array}$ & не выявлено & не выявлено & 10 & не выявлено & не выявлено & 35 \\
\hline Совет муфтиев России ${ }^{8}$ & не выявлено & 3 & 16 & не выявлено & не выявлено & 37 \\
\hline $\begin{array}{l}\text { Федерация еврейских } \\
\text { общин России }\end{array}$ & не выявлено & 3 & 1 & не выявлено & не выявлено & 1 \\
\hline $\begin{array}{l}\text { Буддийская традицион- } \\
\text { ная Сангха России }{ }^{10}\end{array}$ & 1 & 1 & 3 & получают & не выявлено & 3 \\
\hline $\begin{array}{l}\text { Российский Союз } \\
\text { Евангельских христи- } \\
\text { ан-баптистов }^{11}\end{array}$ & не выявлено & 1 & 1 & не выявлено & не выявлено & 4 \\
\hline $\begin{array}{l}\text { Церковь христиан-адвен- } \\
\text { тистов седьмого дня }{ }^{12}\end{array}$ & не выявлено & 1 & 1 & получает & не выявлено & 3 \\
\hline $\begin{array}{l}\text { Российская церковь } \\
\text { христиан веры еван- } \\
\text { гельской }{ }^{13}\end{array}$ & не выявлено & 1 & 2 & не выявлено & не выявлено & 4 \\
\hline
\end{tabular}

Из представленного материала видно, что на сегодняшний день государственные органы власти Российской Федерации всех уровней отдают предпочтение Русской православной церкви, наделяя её особым

6 Официальный сайт Русской Древлеправославной Церкви [Электронный ресурc]. - URL: http://ancient-orthodoxy.narod.ru/ (дата обращения 20.01.2013)

7 Официальный сайт Центрального духовного управления мусульман России [Электронный ресурс]. - URL: http://www.cdum.ru/about/ (дата обращения 20.01.2013)

${ }^{8}$ Официальный сайт Совета муфтиев России [Электронный реcypc]. - URL: http://www.muslim.ru/(дата обращения 20.01.2013)

9 Официальный сайт Федерации еврейских общин России [Электронный pecypc]. - URL: http://www.feor.ru/ (дата обращения 20.01.2013)

10 Официальный сайт Буддийской традиционной Сангхи России [Электронный ресурс]. - URL: http://sangharussia.ru/ news/(дата обращения 20.01.2013)

${ }^{11}$ Официальный сайт Российского Союза Евангельских христиан-баптистов [Электронный ресурс]. - URL: http://baptist.org.ru/(дата обращения 20.01.2013)

12 Официальный сайт христиан адвентистов седьмого дня [Электронный ресурc]. - URL: http://adventist.ru/ ( дата обращения 20.01.2013)

${ }^{13}$ Официальный сайт Христиан веры евангельской [Электронный pecypc]. - URL: http://www.hve.ru/ ( дата обращения 20.01.2013) политическим и социальным статусом через систему договоров и неформальных соглашений. Практика договорных соглашений показывает насущную потребность законодательно закрепить все виды соглашений как официальных, так и неформальных между религиозными организациями и социально-политическими акторами. А также выработать регламент по взаимодействию религиозных организаций с государственными органами власти.

Подвергая анализу социально-политическую привлекательность религиозных организаций, акценты распределяются иначе. На наш взгляд, одна из причин социально-политической привлекательности скрывается не столько в богословской сфере - совпадении религиозных убеждений индивида, группы, участников политического процесса, сколько в социально-психологической привлекательности для человека выражающаяся в непосредственных, эмоциональных и тесных межличностных отношениях, характерных для нетрадиционных религиозных объединений.

Более того, индивиды, чрезмерно сконцентрированные на своём «Я», требуют особенного внимания к себе и своим проблемам, перенося их не только на близкий круг, но и на религиозных служителей. Очень часто эта потребность не реализуется в традиционных религиозных организациях. 
Государство и гражданское общество

В качестве эксперимента, мною были посещены четыре религиозные организации (Русская православная церковь, католическая церковь, религиозная организация «Российский союз евангельских христиан-баптистов», местная религиозная организация «Жатва») как традиционных, так и нетрадиционных вероучений.

Целью посещения было заполнение дневника наблюдений, в котором отслеживалось количество при- хожан, примерный возраст, пол. Проводились личные неформальные беседы с пастырями, прихожанами. Для себя решила определить, какая религиозная организация привлекла лично моё внимание а, следовательно, могла бы привлечь внимание и других верующих.

Результаты эксперимента представлены в виде таблицы «Критерии социально-политической привлекательности религиозных организаций».

Критерии соцчильно-политической привлекательности религиозных организацчй (+) - проявляется (-) -не проявляется

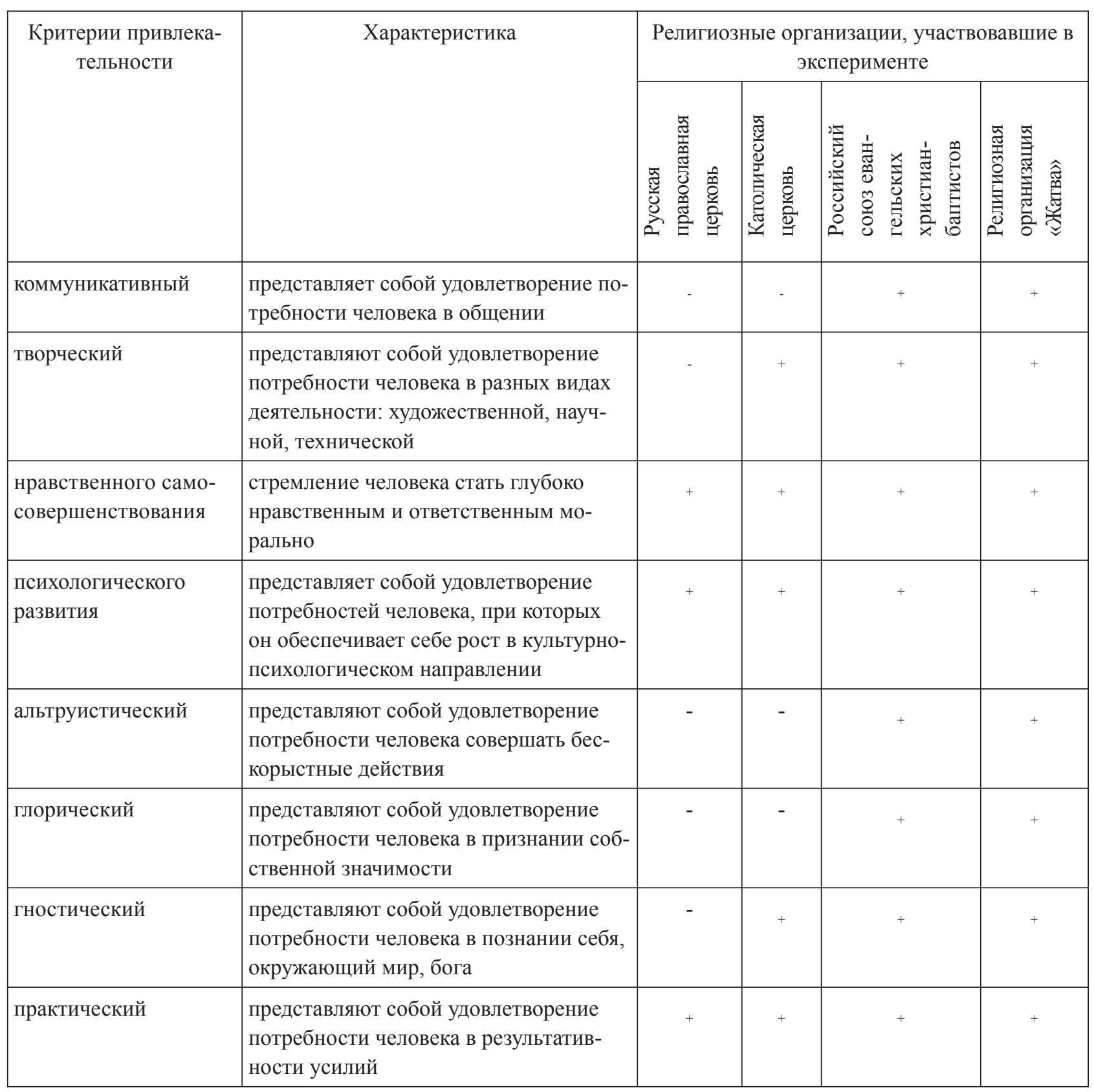




\section{Политика и общество 2 (98) • 2013}

\begin{tabular}{|c|c|c|c|c|c|}
\hline пугнический & $\begin{array}{l}\text { представляют собой удовлетворение } \\
\text { потребности человека в соревнователь- } \\
\text { ной деятельности }\end{array}$ & - & - & + & + \\
\hline $\begin{array}{l}\text { поиск дружеских } \\
\text { связей }\end{array}$ & $\begin{array}{l}\text { представляют собой удовлетворение } \\
\text { потребности человека в дружбе, любви }\end{array}$ & - & - & + & + \\
\hline уважение и поддержка & $\begin{array}{l}\text { представляют собой удовлетворение } \\
\text { потребности человека в уважении и } \\
\text { взаимопомощи }\end{array}$ & + & + & + & + \\
\hline социальный & $\begin{array}{l}\text { представляют собой удовлетворение } \\
\text { потребности человека в реализации } \\
\text { групповых интересов, альтруистиче- } \\
\text { ской направленности, благородства, } \\
\text { заботе о других }\end{array}$ & + & + & + & + \\
\hline
\end{tabular}

Что касается Русской православной церкви, католической церкви, то моё посещение осталось незамеченным ни со стороны прихожан, ни со стороны священнослужителей. Что касается посещений, то наблюдается отток прихожан. Это можно судить и по посещению, и по количеству нищих если раньше они боролись за место возле церкви, их кормили, раздавали одежду, то сейчас 1-2 нищих и тех гонят сами монашки. Во время службы в храмах примерно 10-20 человек. В течение дня храмы посещают люди разного возраста, чаще цыгане и женщины пожилого возраста. Приходят по разным причинам, но в основном, заказать молитвы, купить и поставить свечи. Крещение, венчание в храме, по словам самих монашек, явление редкое 1-2 раза в месяц. Отпевание осуществляется на дому, тоже не часто, молодёжь не отпевают в основном пенсионеров. Чтение молитв во время служения осуществляется на старославянском языке, посещая несколько раз службу выучить эти слова мне, к сожалению не удалось. Само посещение храмов для меня было утомительно, всю службу на ногах отстоять очень тяжело и плюс запах свечей надо иметь хорошее здоровье и хорошую физическую форму, чтобы как истинный верующий посещать регулярно храм и стоять службу.

Например, священник, в чьём ведении находятся несколько приходов, физически не в состоянии уделять большое количество времени каждому прихожанину. Чувствуя себя «ненужными», «оставленными», эти верующие не задерживаются в традиционных религиозных организациях и, подобно кораблю, отправляются в самостоятельное религиозное плавание, в котором рано или поздно возникает необходимость причалить к тому или иному берегу.
Если обратиться к нетрадиционным церквям, то уже после первого посещения мне не удалось остаться незамеченной. Прихожане как мне удалось выяснить братья и сёстры буквально в течение 10-15 минут обратили на меня внимание, познакомились, рассказали много интересного про их веру, пригласили остаться на служение. Служение проходило в атмосфере праздника, в храме в основном была молодёжь, средний возраст примерно от 2035 лет, полового предпочтения выявить не удалось примерно одинаковое количество, как мужчин, так и женщин, причем большое количество семейных пар с детьми разного возраста. Улыбки не сходили с лица были и песни, была и проповедь с хорошими поучительными примерами из жизни. Приятное время препровождение, несомненно, не могло не привлечь мой интерес и расположить к этой вере. Основными ценностями веры является семья, дети.

В связи с этим, социально-политические взаимоотношения религиозных организаций с обществом должны носить личностно-ориентированный характер. Именно это направление позволит выявить и оказать помощь социально незащищённой категории граждан, где государство по отдельным вопросам оказать помощь бессильно, так как действуют шаблонно и в силу действующего законодательства не может идти на компромисс. Нетрадиционные религиозные организации готовы вести диалог и достигать компромисса с социально неблагополучной частью общества, тем самым помогая государству в реализации важнейших внутриполитических функций таких как: социальных, духовных, гражданских и т.д. 
Государство и гражданское общество

Исследуя факторы становления и развития нетрадиционных религиозных групп, нельзя обделить вниманием и вопрос о проповеднической деятельности, от характера которой зависит жизнедеятельность той или иной религиозной организации.

Очевидно, нетрадиционные религиозные организации отличаются активной проповеднической деятельностью. В то время как представители традиционных религий применяют «академические» способы распространения своих взглядов (издание апологетических работ, проведение богословских диспутов, конференций, выступление в СМИ и т.д.), нетрадиционные религиозные организации «идут в народ», отдавая предпочтение непосредственному контакту с потенциальными верующи- ми. Нетрадиционные религиозные организации принципиально делают упор на миссии, организованной по принципу «от человека к человеку», «от дома к дому». Результат подобной стратегии вполне себя оправдывает: теперь на конфессиональной карте наших городов можно встретить не только христианские, но и мусульманские культовые здания, медитативные центры и т. д.

Для более полного изучения взаимодействия религиозных организаций и институтов власти нами были изучены и выделены основные направления значимой социально-политической деятельности религиозных организаций. Результаты исследования представлены в виде схемы «Направления социально-политической деятельности религиозных организаций».

\section{Направления социально-политической деятельности религиозных организаций}

\section{$\mathcal{L}$}

\section{Работа с детьми}

Помощь малообеспеченным

Культурные программы

Работа с молодёжью

Реабилитация наркоманов и алкоголиков

Помощь заключённым

Помощь пожилым и домам престарелых

Помощь детским домам

Выступления в средствах массовой информации

Программы по укреплению семьи

Курсы по изучению культурной традиции

Благотворительные обеды и столовые

Работа с военнослужащими

Создание конфессиональных учебных

заведений для детей

Благотворительные организации и фонды

Помощь инвалидам

Просветительская работа в школах

Медицинская помощь

Помощь больницам

Помощь бездомным

Патронаж

Помощь детям-инвалидам

Обучение сестёр милосердия

Благотворительные акции

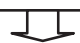

Профилактика ВИЧ и помощь ВИЧ-

инфицированным

Реабилитация бывших заключённых

Милосердие

Помощь беспризорным детям

Помощь социально неблагополучным

семьям

Работа с педагогами

Центры дневного пребывания

Помощь пострадавшим от стихийных

бедствий

Профилактика наркомании

Помощь беженцам

Помощь многодетным семьям

Работа с врачами

Помощь детям заключённых

Пропаганда нравственного образа жизни

Юридическая помощь

Помощь колониям для несовершеннолетних

Помощь хосписам

Работа с трудными подростками

Реабилитация бывших военных

Помощь безработным

Психологическая помощь

Детские дома и приюты

Курсы социальных работников 


\section{Политика и общество 2 (98) • 2013}

Социальная помощь религиозных организаций неоценима она осуществляется самостоятельно каждой религиозной организацией. Однако в современном российском государстве возникает необходимость сотрудничества в рамках правового поля между религиозными организациями и органами власти, а такой правовой поддержки не существует. Возникает необходимость разработки правовых актов регулирующих взаимодействие религиозных организаций и институтов власти всех уровней, а также выработать регламент этих взаимодействий.

Современная Россия испытывает сложный процесс усовершенствования всех областей жизнедеятельности, перехода их на коммерческие отношения. Этот процесс протекает в условиях двойственного и подчас болезненного существования российского общества, сопровождается его резким разделением на богатых и бедных, упадком нравственности, ростом враждебности. Всё это оказывает воздействие на социум и делает его нестабильным.

Вот почему российское государство на всех его уровнях пропагандирует необходимость возврата к нравственным, духовным источникам, прежде всего к православию, обращает пристальное внимание к институту религии, религиозным организациям, как важнейшим составляющим гражданского общества.

Демократизация общественно-политической жизни сняла существовавшие ранее ограничения на деятельность религиозных организаций и участие в ней граждан. В российском государстве идёт глубокий процесс «воссоздания религии», который сопровождается увеличением числа религиозных объединений как традиционных, так и нетрадиционных, возвращаются старые и строятся новые религиозные учреждения, многие политические партии органы государственной власти становятся религиозно направленными.

Современное государство возвращает и выражает содействие в строительстве и реставрации религиозных учреждений, укрепляет сотрудничество с религиозными организациями, ведёт пропаганду религиозности во всех сферах жизни страны и регионов, не смотря на светский характер государства.

Среди отождествляющих себя верующими господствует ориентация безучастного членства в церкви, проявляющаяся в формальной принадлеж- ности к ней. Проявляется «приватизация» веры, через личностно-ориентированного бога. Оказывается важно «как», а не «во что» верить, что в свою очередь порождает в молодёжной среде преобладание «социальной религиозности», для которой свойственна ориентация на социальные установки в контексте религии, а также внутренние духовные потребности человека.

\section{Библиография:}

1. Буддийский традиционный Сангх России [сайт], [Электронный ресурс]. - URL: http://sangharussia. $\mathrm{ru} / \mathrm{news} /($ дата обращения 20.01.2013)

2. Донцев, С.П. Русская православная церковь и государственные институты РФ: механизмы политического взаимодействия. [Текст]: дис. ... канд. полит. наук: 23.00.02/ Донцев Сергей Павлович. - М., 2007. - 274 с. РГБ ОД, $6107-23 / 353$

3. Митрохин Н. А. Русская православная церковь: современное состояние и актуальные проблемы. [Текст] М: Новое литературное обозрение, 2004. $-648 \mathrm{c}$.

4. Осипова, Л.Н. Взаимоотношения государственных институтов и религиозных объединений а современной России. [Текст]: дис. ... канд. полит. наук: 23.00.02 / Осипова Лариса Николаевна. - Уфа, 2004. - 187 с. РГБ ОД, 61:04-23/189

5. Основы социальной концепции Русской Православной Церкви. [Электронный ресурс]. - URL: http://www.patriarchia.ru/db/text/141422.html (дата обращения: 22.03.2012).

6. Российский Союза Евангельских христиан-баптистов [сайт], [Электронный ресурс]. - URL: http:// baptist.org.ru/(дата обращения 20.01.2013)

7. Русская Древлеправославная Церковь [сайт], [Электронный ресурс]. - URL: http://ancientorthodoxy.narod.ru/(дата обращения 20.01.2013)

8. Русская православная церковь [сайт], [Электронный ресурс]. - URL: http://www.patriarchia.ru/ дата (обращения 20.01.2013)

9. Русская Православная старообрядческая Церковь [сайт], [Электронный ресурс]. - URL: http://rpsc. $\mathrm{ru} /($ дата обращения 20.01.2013)

10. Рябых, Ю.А. Участие русской православной церкви в политическом процессе современной России. 
[Текст]: дис. ... канд. полит. наук: 23.00.02 / Рябых Юрий Анатольевич. - М., 2005. - 150 с. - РГБ ОД 61:05-23/348

11. Совет муфтиев России [сайт], [Электронный ресурc]. - URL: http://www.muslim.ru/(дата обращения 20.01.2013)

12. Современные лики теократии / Ж.Т. Тощенко// Мир России.- 2010.-№2.- с. 19-58.- (Духовная жизнь: власть и общество).-Библиограф.: с. 55-58.

13. Социальное партнерство государства и религиозных организаций. Монография - М.: Научный эксперт, 2009. - 232 с.

14. Толковый словарь С.И.Ожегова, Н.Ю.Шведовой [Электронный ресурс]. - URL: http://www. jobtoday.com.ua/slovar/slovo_search.php (дата обращения 20.01.2013).

15. Толковый словарь С.И.Ожегова, Н.Ю.Шведовой [Электронный ресурc]. - URL: http://www.jobtoday. com.ua/slovar/slovo_search.php?pg=11\&cb=2\&keyw $=$ процесс\&jcode $=($ дата обращения 20.01.2013).

16. Толковый словарь С.И.Ожегова, Н.Ю.Шведовой [Электронный ресурc]. - URL: http://www.jobtoday. com.ua/slovar/slovo_search.php?pg=4\&cb=1\&keyw= политика\&jcode= (дата обращения 20.01.2013).

17. Федерация еврейских общин России [сайт], [Электронный ресурc]. - URL: http://www.feor.ru/ (дата обращения 20.01.2013)

18. Центральное духовное управления мусульман России [сайт], [Электронный ресурс]. - URL: http:// www.cdum.ru/about/ (дата обращения 20.01.2013)

19. Церковь христиан адвентистов седьмого дня [сайт], [Электронный ресурс]. - URL: http://adventist.ru/ ( дата обращения 20.01.2013)

20. Церковь Христиан веры евангельской [сайт], [Электронный ресурc]. - URL: http://www.hve.ru/ (дата обращения 20.01.2013)

\section{References (transliteration):}

1. Dontsev, S.P. Russkaya pravoslavnaya tserkov' i gosudarstvennye instituty RF: mekhanizmy politicheskogo vzaimodeystviya. [Tekst]: dis. ... kand. polit. nauk: 23.00.02/ Dontsev Sergey Pavlovich. - M., 2007. - 274 s. RGB OD, 61 07-23/353

2. Mitrokhin N. A. Russkaya pravoslavnaya tserkov': sovremennoe sostoyanie i aktual'nye problemy. [Tekst] M: Novoe literaturnoe obozrenie, 2004. - 648 s.

3. Osipova, L.N. Vzaimootnosheniya gosudarstvennykh institutov i religioznykh ob'edineniy a sovremennoy Rossii. [Tekst]: dis. ... kand. polit. nauk: 23.00.02 / Osipova Larisa Nikolaevna. - Ufa, 2004. 187 c. RGB OD, 61:04-23/189

4. Ryabykh, Yu.A. Uchastie russkoy pravoslavnoy tserkvi v politicheskom protsesse sovremennoy Rossii. [Tekst]: dis. ... kand. polit. nauk: 23.00.02 / Ryabykh Yuriy Anatol'evich. - M., 2005. - 150 s. RGB OD 61:05-23/348

5. Sovremennye liki teokratii / Zh.T. Toshchenko// Mir Rossii.- 2010.-№2.-s. 19-58.- (Dukhovnaya zhizn’: vlast' i obshchestvo).-Bibliograf.: s. 55-58.

6. Tolkovyy slovar' S.I.Ozhegova, N.Yu.Shvedovoy [Elektronnyy resurs]. - URL: http://www.jobtoday. com.ua/slovar/slovo_search.php (data obrashcheniya 20.01.2013).

7. Tolkovyy slovar' S.I.Ozhegova, N.Yu.Shvedovoy [Elektronnyy resurs]. - URL: http://www.jobtoday. com.ua/slovar/slovo_search.php?pg=11\&cb=2 $\&$ keyw $=$ protsess $\&$ jcode $=\quad$ (data obrashcheniya 20.01.2013).

8. Tolkovyy slovar' S.I.Ozhegova, N.Yu.Shvedovoy [Elektronnyy resurs]. - URL: http://www.jobtoday. com.ua/slovar/slovo_search.php?pg=4\&cb=1\&keyw $=$ politika\&jcode $=($ data obrashcheniya 20.01.2013 $)$. 